Article

\title{
PREPARATION AND CHARACTERIZATION OF CARBON FROM THE FRUIT OF BRAZIL NUT TREE ACTIVATED BY PHYSICAL PROCESS
}

\author{
Michelle Ferreira da Silva Rimoli ${ }^{2} \odot$, Roberta Martins Nogueira ${ }^{2 *}$, Stela Regina Ferrarini ${ }^{3} \odot$, Pryscila \\ Machado de Castro ${ }^{4}\left(-\right.$ and Evaldo Martins Pires $^{5}$ ()
}

\footnotetext{
${ }^{1}$ Received on 21.03.2019 accepted for publication on 09.08.2019.

${ }^{2}$ Universidade Federal de Mato Grosso, Instituto de Ciências da Agrárias e Ambientais, Sinop, MT - Brasil. E-mail: <michellefsrimoli@hotmail. com $>,<$ robertamnogueira@gmail.com $>$.

${ }_{3}^{3}$ Universidade Federal de Mato Grosso, Instituto de Ciências da Saúde, Sinop, MT - Brasil. E-mail: <srferrarini@gmail.com>.

${ }^{4}$ Universidade Federal de Mato Grosso, Mestre em Ciências Ambientais, Sinop, MT - Brasil.. E-mail: <pryscilamcastro@gmail.com>.

${ }^{5}$ Universidade Federal de Mato Grosso, Instituto de Ciências Naturais, Humanas e Sociais, Sinop, MT - Brasil. E-mail: <evaldo.pires@gmail.com>.

*Corresponding author.
}

\begin{abstract}
Activated carbon is the name of a big group of materials that presents high degree of porosity and, consequently, an extended internal surface area, with physical and chemical adsorption properties. Innumerous raw materials can be used as precursors, especially biomass. The objective of this study was to obtain activated carbon from physical activation of the fruit of Brazil nut tree ("ouriço") and to evaluate its physical and chemical properties in function of the differences between the temperatures and atmospheres of activation. The samples were carbonized at 3 different temperatures and the carbons were activated under atmosphere saturated by $\mathrm{CO}_{2}$ or steam. The results showed the influence of activation temperature and atmosphere on physicochemical characteristics of carbon. The carbon from woody Brazil nut seed capsule activated by $\mathrm{CO}_{2}$ and steam at different temperatures had a microporous profile, indicating its use to adsorb organic molecules of small dimensions. Basic characteristic was observed on samples and the carbon produced was thermally stable. Best quality was attributed to carbon activated by steam at $800{ }^{\circ} \mathrm{C}$.
\end{abstract}

Keywords: Activated carbon; Adsorption; Activation method.

\section{PREPARAÇÃO E CARATERIZAÇÃO DO CARVÃO DO FRUTO DA CASTANHEIRA-DO-BRASIL ATIVADO POR PROCESSOS FÍSICOS}

RESUMO - Carvão ativado é o nome de um grande grupo de materiais que apresentam alto grau de porosidade e, consequentemente, extensa área superficial interna, com propriedades adsortivas de caráter físico e químico. Inúmeros materiais podem ser utilizados como precursores, especialmente biomassa. O objetivo deste trabalho foi obter carvão ativado a partir da ativação física do fruto da castanheira-do-brasil ("ouriço") e avaliar suas propriedades fisico químicas em função das diferenças entre as temperaturas e atmosferas de ativação. As amostras foram carbonizadas em 3 diferentes temperaturas e o carvão produzido foi ativado sob atmosfera saturada por $\mathrm{CO}_{2}$ e vapor d'água. Os resultados mostraram a influência da temperatura e atmosfera de ativação nas propriedades fisico-químicas do carvão. O carvão do ouriço ativado por $\mathrm{CO}_{2}$ e por vapor apresentou perfil microporoso, indicando seu uso como adsorvente de moléculas orgânicas de pequenas dimensões. Foi observado um caráter básico nas amostras e o carvão produzido foi termicamente estável. Melhor qualidade foi atribuida ao carvão ativado por vapor d'água a $800{ }^{\circ} \mathrm{C}$.

Palavras-chave: Carvão ativado; Adsorção; Ativação.

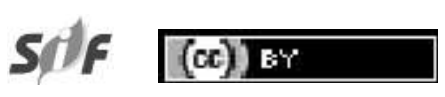

Revista Árvore 2019;43(2):e430206

http://dx.doi.org/10.1590/1806-90882019000200006 


\section{INTRODUCTION}

Activated carbon is the name for a big group of porous materials based on a carbonic matrix. Carbonaceous materials are carbonized after their impregnation with chemicals, it is called chemical activation; or a char is treated with oxidizing gases, a process named as physical activation. These conditions accord a high degree of porosity and, consequently, an extended internal surface area, withal physical and chemical adsorption properties (Rodriguez-Reinoso and Silvestre-Albero, 2016).

The main differences between activation process are: carbonization and activation are unseparated steps during chemical activation, whereas they are independent during physical activation (Prauchner and Rodríguez-Reinoso 2012). Physical activation presents several advantages and disadvantages compared to chemical activation. The main advantages are the low cost, considering there is no need of acquiring activating agents, such as acid or basic chemicals, and there is no need of an additional washing stage. Moreover, these chemicals can be corrosive (Maciá-Agulló et al., 2004).

The characteristics of activated carbons are due to the precursor material and the activation method (Bhatnagar and Sillanpää, 2010). A plenty of lignocellulosic materials were employed as precursors (Ahmad et al., 2007; Daud et al., 2000; Jaguaribe et al., 2005; Melo et al., 2015; Tsai et al., 2001). However, other materials such as animal bones and petroleum coke can also be used (Djilani et al., 2016; Kawano et al., 2008).

The woody Brazil nut (Bertholletia excelsa) seed capsule has high lignocellulose content (Rambo et al., 2015; Scussel et al., 2014) which is an important feature for obtaining a high quality carbon (Yang et al., 2007). As a byproduct, it has low cost, which, added to the lower cost of physical activation, may produce a cheaper activated carbon, to be used: in the treatment of water supply (Borges et al., 2016), in medical and environmental applications (Alkhatib and Zailaey, 2015), in natural gas storage (Gottipati et al., 2012), in the filtering of compounds used in agricultural activity (Melo et al., 2015), and others.

In the present study, activated carbon was obtained from physical activation of woody Brazil nut seed capsule. Its physical and chemical properties were characterized in function of the differences between the temperatures and atmospheres of activation.

\section{MATERIAL AND METHODS}

Samples of woody Brazil nut seed capsule were fragmented into 2 to $3 \mathrm{~cm}$ pieces and then washed in running water and kept in an oven with forced air circulation at $105^{\circ} \mathrm{C}$ for 24 hours for drying.

Cleaned and dried material was fitted inside a metal cylindrical container (length: $720 \mathrm{~mm}$; internal diameter: $68 \mathrm{~mm}$ ) and the filled container was placed in a tubular oven (FT-1200/H1Z, Fortelab, São Carlos, $\mathrm{SP}$, Brazil) with heat rate of $10^{\circ} \mathrm{C} / \mathrm{min}$. The oven was adjusted to the pyrolysis temperature and the samples were maintained at these temperatures for five hours. The tested temperatures were $600{ }^{\circ} \mathrm{C}, 700{ }^{\circ} \mathrm{C}$ and $800{ }^{\circ} \mathrm{C}$. Shortly after the pyrolysis of the material, the atmosphere was saturated with an oxidizing agent for 40 minutes, for the activation of the carbon. The tested agents were $\mathrm{CO}_{2}$ (pressure of $0.58 \mathrm{kgf.cm}{ }^{-2}$ ) and steam at $1 \mathrm{kgf.cm}{ }^{-2}$ from a vertical boiler (EIT-VL, EIT, Paiçandu, PR, Brazil).

Water, volatile, ash and fixed carbon contents were determined according to the method standardized by ASTM D 1762-84 (ASTM D 1762-84, 2007). The results were expressed as a percentage in dry basis, except for water content which was expressed as a percentage in wet basis. The $\mathrm{pH}$ values were measured using the standard test method ASTM D 3838-80 (ASTM D 3838-80, 1999) and bulk density by the standard test method ASTM D 2854-09 (ASTM D 2854-09, 2009). Activated carbon yield was determined by weighing the precursor material that filled the container and the material removed from the oven, after activation. The result was expressed as a percentage in wet basis.

The absorption bands in the infrared region of the activated carbon samples were determined in a Fourier transform (FTIR) spectrometer equipped with an attenuated total reflectance (ATR), (Spectrum BXII, Perkin Elmer, Billerica, MA, USA) in the region between 4000 and $400 \mathrm{~cm}^{-1}$, with resolution of $16 \mathrm{~cm}^{-1}$.

Samples of activated carbon were submitted to BET (Brunauer, Emmett e Teller) analysis (Tristar II Kr 3020, Micromeritics, Norcross, GA, USA) to

Revista Árvore 2019;43(2):e430206 
determine the specific surface area. The distribution for microporous size was analyzed by DFT (Density Functional Theory) method.

The thermogravimetric analysis (TGA) curves were determined in a thermogravimetric analyzer (SDT Q600, TA Instruments, New Castle, DE, USA), only for the samples that presented the smallest contents of water and volatile and the highest yield, $\mathrm{pH}$ and content of fixed carbon, for both atmospheres. The explored temperature ranged from $20{ }^{\circ} \mathrm{C}$ to 1000 ${ }^{\circ} \mathrm{C}$ at a heat rate of $10{ }^{\circ} \mathrm{C} \cdot \mathrm{min}^{-1}$, under atmosphere of ultrapure air (100 mL. $\left.\mathrm{min}^{-1}\right)$.

A full $2^{3}$ factorial coupled with statistical analysis of the results, by using analysis of variance (ANOVA) was carried using Action Stat Pro (ESTATCAMP and DIGUP, 2017). Five replications were used for all the physicochemical properties analyzed.

\section{RESULTS}

The temperature influenced the yield $(\mathrm{F}=51.69$; $\mathrm{p}<0.05), \mathrm{pH}(\mathrm{F}=35.95 ; \mathrm{p}<0.05)$, volatiles content $(\mathrm{F}=123.04 ; \mathrm{p}<0.05)$, ash content $(\mathrm{F}=8.56 ; \mathrm{p}<$ $0.05)$ and fixed carbon $(\mathrm{F}=95.51 ; \mathrm{p}<0.05)$. There was no significant interaction between temperature and atmospheres of activation for any parameters. Physicochemical composition data of the activated carbon followed normal distribution, by AndersonDarling testing (Table 1).

Table 1 - Yield, Water content, Volatile, Ash, Fixed carbon, Bulk density and $\mathrm{pH}$ for samples activated by $\mathrm{CO} 2$ and steam at temperatures of 600,700 and $800^{\circ} \mathrm{C}$

Tabela 1 - Rendimento, teor de água, voláteis, cinzas, carbono fixo, massa especifica e pH para amostras ativadas por CO2 e vapor a temperatura de 600,700 e $800^{\circ} \mathrm{C}$

\begin{tabular}{|c|c|c|c|}
\hline Temperature $\left({ }^{\circ} \mathrm{C}\right)$ & $\mathrm{CO}_{2}$ & Steam & $p 1$ \\
\hline & \multicolumn{3}{|c|}{ Yield (\%) } \\
\hline 600 & $26.38 \pm 0.51 \mathrm{a}$ & $25.82 \pm 0.36 \mathrm{a}$ & 0.4004 \\
\hline 700 & $23.78 \pm 0.46 \mathrm{~b}$ & $24.48 \pm 0.46 \mathrm{a}$ & 0.3135 \\
\hline \multirow[t]{2}{*}{800} & $21.86 \pm 0.42 \mathrm{c}$ & $21.34 \pm 0.43 \mathrm{~b}$ & 0.4126 \\
\hline & \multicolumn{3}{|c|}{ Water content $(\%)$} \\
\hline 600 & $1.53 \pm 0.09 \mathrm{a}$ & $0.48 \pm 0.05 \mathrm{a}$ & $<0.001$ \\
\hline 700 & $1.55 \pm 0.18 \mathrm{a}$ & $0.58 \pm 0.20 \mathrm{a}$ & 0.0072 \\
\hline \multirow[t]{2}{*}{800} & $1.24 \pm 0.28 \mathrm{a}$ & $0.45 \pm 0.08 \mathrm{a}$ & 0.0284 \\
\hline & \multicolumn{3}{|c|}{ Volatile (\%) } \\
\hline 600 & $11.10 \pm 0.41 \mathrm{a}$ & $10.26 \pm 0.43 \mathrm{a}$ & 0.1935 \\
\hline 700 & $7.47 \pm 0.32 \mathrm{~b}$ & $6.96 \pm 0.14 \mathrm{~b}$ & 0.1954 \\
\hline \multirow[t]{2}{*}{800} & $6.42 \pm 0.18 \mathrm{~b}$ & $5.83 \pm 0.19 \mathrm{c}$ & 0.0588 \\
\hline & \multicolumn{3}{|c|}{ Ash (\%) } \\
\hline 600 & $2.08 \pm 0.12 \mathrm{a}$ & $1.72 \pm 0.06 \mathrm{a}$ & 0.0308 \\
\hline 700 & $1.79 \pm 0.08 \mathrm{a}$ & $1.69 \pm 0.09 \mathrm{a}$ & 0.4859 \\
\hline \multirow[t]{2}{*}{800} & $2.12 \pm 0.07 \mathrm{a}$ & $2.09 \pm 0.08 \mathrm{~b}$ & 0.7813 \\
\hline & \multicolumn{3}{|c|}{ Fixed carbon $(\%)$} \\
\hline 600 & $85.27 \pm 0.42 \mathrm{a}$ & $87.53 \pm 0.40 \mathrm{a}$ & 0.0044 \\
\hline 700 & $89.18 \pm 0.44 b$ & $90.74 \pm 0.30 \mathrm{~b}$ & 0.0198 \\
\hline \multirow[t]{2}{*}{800} & $90.20 \pm 0.17 \mathrm{~b}$ & $91.61 \pm 0.24 \mathrm{~b}$ & 0.0014 \\
\hline & \multicolumn{3}{|c|}{ Bulk density $\left(\mathrm{g} . \mathrm{cm}_{-3}\right)$} \\
\hline 600 & $0.24 \pm 0.01 \mathrm{a}$ & $0.24 \pm 0.01 \mathrm{a}$ & 0.4323 \\
\hline 700 & $0.25 \pm 0.01 \mathrm{a}$ & $0.25 \pm 0.01 \mathrm{a}$ & 0.7355 \\
\hline \multirow[t]{2}{*}{800} & $0.25 \pm 0.01 \mathrm{a}$ & $0.23 \pm 0.02 \mathrm{a}$ & 0.0946 \\
\hline & \multicolumn{3}{|c|}{$\mathrm{pH}$} \\
\hline 600 & $9.00 \pm 0.08 \mathrm{a}$ & $9.17 \pm 0.04 \mathrm{a}$ & 0.1302 \\
\hline 700 & $9.10 \pm 0.06 \mathrm{a}$ & $9.14 \pm 0.08 \mathrm{a}$ & 0.1302 \\
\hline 800 & $9.58 \pm 0.04 \mathrm{~b}$ & $9.64 \pm 0.08 \mathrm{~b}$ & 0.4938 \\
\hline
\end{tabular}

*Means followed by the same letter in the column, for the same parameter, don't differ by Tukey test at $\mathrm{p}<0.05$.

${ }^{1} \mathrm{H}_{0}: \mu_{\mathrm{t} \text { vapor }}=\mathrm{e} \mathrm{H}_{1}: \mu_{\mathrm{t} \text { vapor }} \neq \mu_{\mathrm{t}} \mathrm{CO}_{2}$ 
Higher results for yield were obtained from carbon activated by $\mathrm{CO}_{2}$ at $600{ }^{\circ} \mathrm{C}$, and from those activated by steam at $600{ }^{\circ} \mathrm{C}$ and $700{ }^{\circ} \mathrm{C}$. Smaller contents of volatile were acquired at temperatures of $600{ }^{\circ} \mathrm{C}$ and $700{ }^{\circ} \mathrm{C}$ for the activation with $\mathrm{CO}_{2}$, and at $800{ }^{\circ} \mathrm{C}$ by steam activation. Steam at 800 ${ }^{\circ} \mathrm{C}$ allows higher ash contents. For fixed carbon, either $\mathrm{CO}_{2}$ and steam at $700{ }^{\circ} \mathrm{C}$ and $800{ }^{\circ} \mathrm{C}$ allowed higher results. The temperature of $800{ }^{\circ} \mathrm{C}$, for both activation atmospheres, allowed greater basicity to samples (Table 1).

The activation by steam, regardless of the temperature, allowed smaller water contents, compared to those activated by $\mathrm{CO}_{2}$. The results for ash content of samples activated by steam and $\mathrm{CO}_{2}$, were different only for the temperature of 600 ${ }^{\circ} \mathrm{C}$. Steam allowed higher fixed carbon under any temperature (Table 1).

The spectrum on infrared region (IR) for precursor showed vibrational bands at 3348, 2924, $1736,1654,1594,1510,1466,1416,1370,1330$, $1228,1160,1107,1026$ and $668 \mathrm{~cm}^{-1}$. For carbon activated by $\mathrm{CO}_{2}$, there were vibrational bands at $2884 \mathrm{~cm}^{-1}$ for all temperatures; at $1584 \mathrm{~cm}^{-1}$ only for temperatures of 600 and $700{ }^{\circ} \mathrm{C} ; 1134 \mathrm{~cm}^{-1}$ for 700 ${ }^{\circ} \mathrm{C}$ and at 984 and $1563 \mathrm{~cm}^{-1}$ for temperature of 800 ${ }^{\circ} \mathrm{C}$ (Figure 1a). For carbon activated by steam, there were vibrational bands at $2928 \mathrm{~cm}^{-1}$ for 600 e 800 ${ }^{\circ} \mathrm{C} ; 953 \mathrm{~cm}^{-1}$ for 700 and $800{ }^{\circ} \mathrm{C} ; 1127 \mathrm{~cm}^{-1}$ for 800 ${ }^{\circ} \mathrm{C} ; 2891 \mathrm{~cm}^{-1}$ for $700{ }^{\circ} \mathrm{C}$; 920,847 and $771 \mathrm{~cm}^{-1}$ for temperature of $600{ }^{\circ} \mathrm{C}$ (Figure 1b).

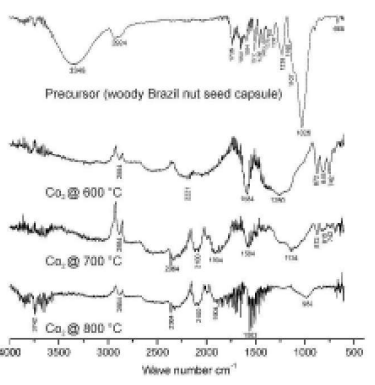

(a)

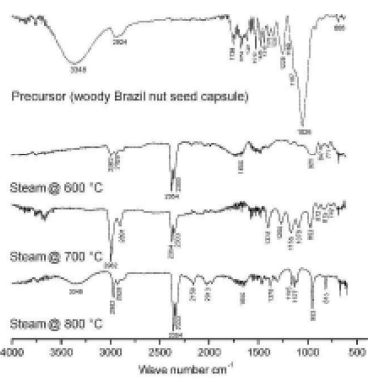

(b)
Figure 1 - Spectrum on infrared region for precursor material, carbon activated by $\mathrm{CO} 2$ at any temperature (a) and carbon activated by steam at any temperature (b).

Figura 1 - Espectro na região do infravermelho para o material precursor, carvão ativado por $\mathrm{CO} 2 \mathrm{em}$ todas as temperaturas (a) e carvão ativado por vapor em todas as temperaturas (b).
The specific surface area for samples activated by $\mathrm{CO}_{2}$ at 600,700 and $800{ }^{\circ} \mathrm{C}$ were $15.8,55.0$ and $395.0 \mathrm{~m}^{2} \mathrm{~g}^{-1}$, respectively. From steam activation the results were $125.0,320.0$ and $401.0 \mathrm{~m}^{2} \mathrm{~g}^{-1}$, for samples activated at 600,700 and $800{ }^{\circ} \mathrm{C}$, respectively.

The $\mathrm{N}_{2}$ sorption/desorption isotherm for carbon activated by both atmospheres showed high adsorption of $\mathrm{N}_{2}$ under low pressures (Figure $2 \mathrm{a}$ and $\mathrm{b}$ ) and higher intensity of porous of $1.16,1.17$ and $1.17 \mathrm{~nm}$, for temperatures of 600,700 and $800{ }^{\circ} \mathrm{C}$, respectively (Figure 3a). For the samples activated by steam at $600{ }^{\circ} \mathrm{C}$, the porous of $1.26 \mathrm{~nm}$ was the most founded, followed by 1.0 and $1.7 \mathrm{~nm}$ for samples activated at 700 and $800{ }^{\circ} \mathrm{C}$ for the same atmosphere, respectively (Figure 3b).

The thermogravimetric analysis (TGA) curves, for both activation methods, showed two inflection points defining three ranges for mass loss. Considering

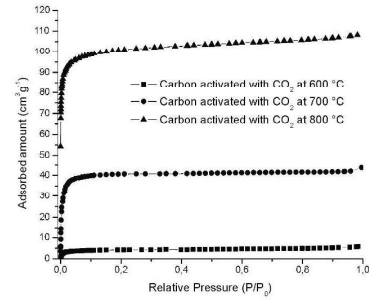

(a)

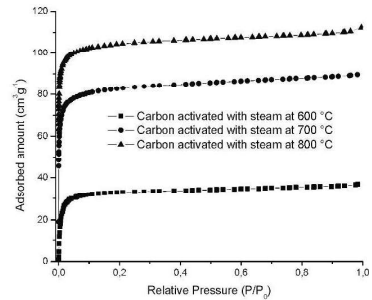

(b)
Figure 2 - Isotherm of sorption/desorption of N2 at $120{ }^{\circ} \mathrm{C}$ for carbon activated by $\mathrm{CO} 2$ (a) and steam (b) at any temperatures.

Figura 2 -Isotermas de sorção/dessorção de N2 a $120{ }^{\circ} \mathrm{C}$ para o carvão ativado por CO2 (a) e vapor (b) em todas as temperaturas.

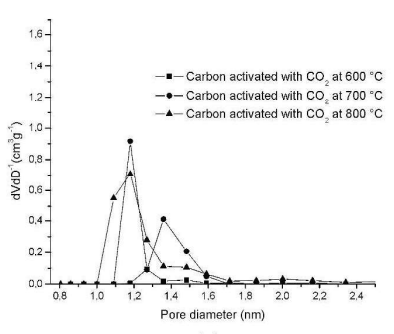

(a)

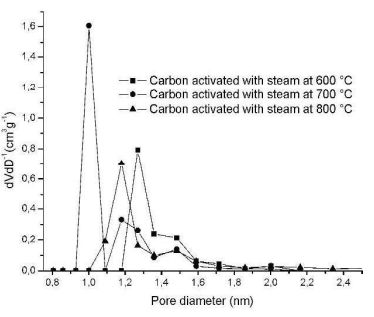

(b)
Figure 3 - Distribution of amount of porous diameter for carbon activated by $\mathrm{CO} 2$ (a) and by steam (b) at any temperature.

Figura 3 - Distribuição dos diâmetros de poros para o carvão ativado por $\mathrm{CO} 2$ (a) e por vapor (b) em todas as temperaturas.

\section{Revista Árvore 2019;43(2):e430206}


the samples activated by $\mathrm{CO}_{2}$, there was a mass loss of $3.08 \%$ up to $150{ }^{\circ} \mathrm{C}, 0.67 \%$ at temperatures ranging from 600 to 700 and $8.62 \%$ above $700{ }^{\circ} \mathrm{C}$. For the activation by steam, mass losses were $9.79 \%, 0.56 \%$ and $16.78 \%$ for temperatures up to $150{ }^{\circ} \mathrm{C}$, between 600 and $700{ }^{\circ} \mathrm{C}$ and above $700{ }^{\circ} \mathrm{C}$, respectively (Figure 4).

\section{DISCUSSION}

Yields were influenced by the temperature but not by the atmosphere. This fact allows to infer that yield is defined during carbonization step, when volatile is released, and high rates of mass loss are observed (Lua and Guo, 2001; Rodríguez-Reinoso et al., 1995; Yang and Lua, 2003). So, since higher temperatures are acquired, smaller yields are observed. Similar behavior was observed for activated carbon from pistachio husk (Yang and Lua, 2003) and from palm trunk (Ahmad et al., 2007), where higher yields were getting from lower temperatures of carbonization, regardless of the activation atmosphere. Whereas the composition of biomass in general, yields close to 30 $\%$ are considered fair (Nobre et al., 2015b).

Neither the temperature nor the atmosphere of activation influenced water content, since water is volatilized up to $200{ }^{\circ} \mathrm{C}$ during carbonization step (Pastor-Villegas et al., 1999). However, higher temperatures of carbonization can contribute to hygroscopicity due to increasing on porous formation (Boas et al., 2010) The hygroscopic feature of the activated carbon allows chemical-physical adsorption

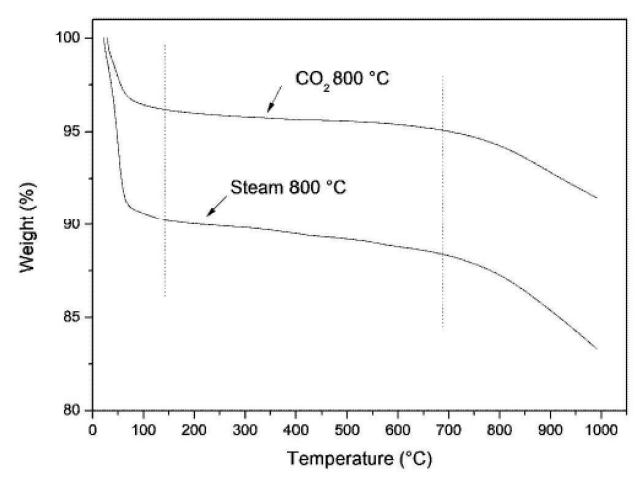

Figure 4 - TGA curves from samples of carbon activated by $\mathrm{CO} 2$ and steam at $800{ }^{\circ} \mathrm{C}$.

Figura 4 - Curvas TGA das amostras de carvão ativado por $\mathrm{CO} 2$ e por vapor a $800^{\circ} \mathrm{C}$. of water inside the porous (Ahmad et al., 2007; Anisuzzaman et al., 2015). So, during the sample handling, water may be absorbed from air moisture. Lower water contents are desirable, since high water contents are related to decreasing on mechanic resistance of activated carbon, consequently, dust generation (Boas et al., 2010).

Releasing of volatile is due to the change to vapor phase of several molecules, by the action of the carbonization temperature (Silva and Brito, 1990). The atmosphere change during the activation step is also important for the residual volatile in the activated carbon. During this stage, the gas permeates into solid matter, contributing to desorption, distillation and removal of volatile that still existed in carbon. Also, activation gases contribute to stabilization of the radical acquired during thermal decomposition, boosting the volatile release (Ahmad et al., 2007). The formation of micro and macro pores is influenced by volatile release, which means that high volatile content in the activated carbon may imply a low surface area (Zhang et al., 2004). Volatile contents higher than 11 $\%$ were presented by other studies in similar conditions of carbonization and activation of the biomass (Ahmad et al., 2007; Róz et al., 2015; Yang and Lua, 2003), disclosing the high quality of the activated carbon from woody Brazil nut seed capsule.

Ash content of activated carbon is related to the composition of precursor and the characteristics of the process of carbonization and activation, since the latter may allow the contamination of the carbon with inert matter (Collet, 1956; Silva and Brito, 1990). Lower ash content may also contribute to indicate the quality of activated carbon (Jaguaribe et al., 2005). As a non-carbonic mineral additive, it may impair adsorption due to changes in interaction between carbon surface and the species to be adsorbed (Bautista-Toledo et al., 2005). Besides blocking pores in carbon and its hydrophilic characteristic, ash increases water adsorption rather than compounds of interest (Ahmedna et al., 2000; Brum et al., 2008). In general, commercial activated carbon presents ash contents ranging from $10 \%$ to $15 \%$ (Jaguaribe et al., 2005; Lopes et al., 2013), far above those found in this work.

High content of fixed carbon confers a matrix able to generate functional groups or surficial complex, that serves as bond sites to adsorption of compounds of 
interest (Aznar, 2011; Mohan and Pittman Jr., 2006). Negative correlation with yield (Brito et al., 1987) and positive correlation with temperature (Róz et al., 2015) are observed during carbonization step. Increasing on temperature leads to losses of condensable and noncondensable compounds, as $\mathrm{CO}$ and $\mathrm{CO}_{2}$ (Pinheiro et al., 2005; Róz et al., 2015; Yang et al., 2007), reducing yield and fixing residual carbon.

$\mathrm{pH}$ may indicate the presence of groups on carbon surface. High values show a low index of acid groups on activated carbon (Strelko and Malik, 2002). Complexes formed between carbonic matrix and oxygen atoms can determine the acidic or basic characteristics of the activated carbon (Aznar, 2011; Mohan and Pittman Jr., 2006; Wibowo et al., 2007). The basic characteristic of the activated carbon is due to the high temperature of activation and to the activation atmosphere. Both parameters collaborate to the breakdown of bonds in the carbonic matrix and to a new arrangement with gases that compose the atmosphere (Leon y Leon et al., 1992; Mohan and Pittman Jr., 2006; Pereira et al., 2003; Wibowo et al., 2007).

The chemical surface of the activated carbon determines the capacity to retain water, catalytic characteristics, acidic or basic feature and the capacity of adsorption (Salame and Bandosz, 2001). It is related to the presence of heteroatoms (oxygen, hydrogen and nitrogen), also the atom of carbon inside the matrix (El-Sayed and Bandosz, 2004; Salame and Bandosz, 2001).

There was a broad band at $3348 \mathrm{~cm}^{-1}$ in the precursor's spectrum (woody nut seed capsule), attributed to a vibrational stretch of hydroxyl group (O-H) linked to hydrogen for alcohols and phenols, possibly due to moisture of the sample (Ramos et al., 2009; Yang and Lua, 2003). The same band was founded for other precursors used for activated carbon production (Ramos et al., 2009). Vibrations corresponding to $\mathrm{v}(\mathrm{C}-\mathrm{H})$ of alkanes $(\mathrm{CH} 3$ and $\mathrm{CH} 2)$ were observed at $2924 \mathrm{~cm}^{-1}$ (Ramos et al., 2009; Yang and Lua, 2003). $\mathrm{CH}_{2}$ and $\mathrm{CH}_{3}$ groups are confirmed for bands at 1446 and $1370 \mathrm{~cm}^{-1}$, typical for angular deformation of these groups (Gomez-Serrano et al., 1996; Jagtoyen et al., 1992; Yang and Lua, 2003). Potential olefinic $\vee(\mathrm{C}=\mathrm{C})$ absorption in the sample allows signals at $1654 \mathrm{~cm}^{-1}$, other two bands around 1510 and $1416 \mathrm{~cm}^{-1}$ can be due to stretch of $\mathrm{C}=\mathrm{C}$ in aromatic rings (Yang and Lua, 2003). A band at 1330 $\mathrm{cm}^{-1}$ can be due to $\mathrm{v}(\mathrm{C}=\mathrm{O})$ vibrations of carboxilated groups and $\mathrm{C}-\mathrm{O}$ stretch vibration is observed between 1300 and $900 \mathrm{~cm}^{-1}$. The band at $1228 \mathrm{~cm}^{-1}$ and the shoulder at $1660 \mathrm{~cm}^{-1}$ indicate the presence of esters (R-CO-O-R'), ethers (R-O-R') or other phenolic groups on precursor. The other shoulder observed at $1107 \mathrm{~cm}^{-1}$ associated to the band at $1026 \mathrm{~cm}^{-1}$ can be associated to alcohol groups (R-OH). Finally, the band at $668 \mathrm{~cm}^{-1}$ represents $\gamma(\mathrm{OH})$ (Yang and Lua, 2003).

The bands at: $2928 \mathrm{~cm}^{-1}$ for carbon activated by steam at 600 and $800{ }^{\circ} \mathrm{C} ; 2891 \mathrm{~cm}^{-1}$ also for activation by steam at $700^{\circ} \mathrm{C}$; and $2884 \mathrm{~cm}^{-1}$ for activation by $\mathrm{CO}_{2}$ at all temperatures, can be attributed to ether group (-O-CH3) and/or to $\mathrm{C}-\mathrm{H}$ bonds, symmetric or asymmetric, of methyl and methylene groups (Ahmad et al., 2007). Bands at $1584 \mathrm{~cm}^{-1}$ for carbons activated by $\mathrm{CO} 2$ at temperatures of 600 and $700{ }^{\circ} \mathrm{C}$ and at $1134 \mathrm{~cm}^{-1}$ for temperature of $800{ }^{\circ} \mathrm{C}$ represent the stretch of carbonyl group in quinone, also the structure of $\gamma$-pyrone with strong vibrations of the $\mathrm{C}=\mathrm{O}$ and $\mathrm{C}=\mathrm{C}$ combination (Ahmad et al., 2007; Tsai et al., 2001). At $1127 \mathrm{~cm}^{-1}$, the band found in the samples activated by steam at $800{ }^{\circ} \mathrm{C}$, and at 1134 $\mathrm{cm}^{-1}$ for carbon activated by $\mathrm{CO} 2$ at $700{ }^{\circ} \mathrm{C}$, represent ketones, alcohols, pyrones and aromatic deformations in C-H plan (Ahmad et al., 2007). The bands at 984 $\mathrm{cm}^{-1}$ (carbon activated by $\mathrm{CO} 2$ at $800{ }^{\circ} \mathrm{C}$ ), $953 \mathrm{~cm}^{-1}$ (carbon activated by steam at 700 and $800{ }^{\circ} \mathrm{C}$ ) and $920 \mathrm{~cm}^{-1}$ (carbon activated by steam at $600{ }^{\circ} \mathrm{C}$ ) can be due to vibration of ethers (-C-O-C-) (Ahmad et al., 2007). The bands at 847 and $771 \mathrm{~cm}^{-1}$ found in the samples activated by steam at $600^{\circ} \mathrm{C}$ can be related to $\mathrm{C}-\mathrm{H}$ out of the plan in aldehydes - $\mathrm{CHO}$, compounds of pyranose and others benzene derivatives (Ahmad et al., 2007).

The basic characteristic of the carbon confers greater capacity of adsorption of acidic substances (Leon y Leon et al., 1992; Mohan and Pittman Jr., 2006; Pereira et al., 2003; Wibowo et al., 2007). The formation of structures of pyrone, ether and groups carbonyl contributes to the basic characteristic of the produced carbon.

The results for specific surface area, both for the carbon activated by $\mathrm{CO}_{2}$ and by steam, are considered fair for activated carbons from wood pyrolysis (Herzog et al., 2006). That fact indicates the quality of woody

Revista Árvore 2019;43(2):e430206 
Brazil nut seed capsule as a precursor for activated carbon production, besides being a raw material of low cost, renewable and abundantly found.

Independent of the atmosphere of activation, the samples presented a microporous profile, confirmed by the higher adsorption volume of $\mathrm{N}_{2}$ under low pressure (Sun and Webley, 2010) and by the identification of peaks at diameter smaller than 2 nm (20 A) (Ahmad et al., 2007). Activated carbons with microporous profile provide high capacity of adsorption of organic molecules of small dimensions, with potential to retain gases and common solvents (Nobre et al., 2015a).

From BET analysis, the microporous profile was confirmed for both activation process, since the isotherms were type I, typical of microporous materials with external surfaces relatively small (Sing et al., 1985). Type I isotherms confer characteristic of chemisorption for activated carbon (Shaji and Zachariah, 2017), on that case, the adsorption is limited by the volume of accessible micropores instead of internal surface area (Sing et al., 1985). This type of isotherm is typical for carbon produced from biomass as a precursor (Oliveira et al., 2016; Yang and Lua, 2003). Pore distribution was not affected by activation atmosphere, indicating that woody Brazil nut seed capsule can be used as a precursor independent of the atmosphere used.

From thermogravimetric curves, both carbons activated by $\mathrm{CO}_{2}$ and activated by steam, at $800{ }^{\circ} \mathrm{C}$, presented similar thermal stability. The initial mass loss observed at temperatures up to $200{ }^{\circ} \mathrm{C}$ can be explained by water evaporation (Pastor-Villegas et al., 1999), which could have been adsorbed during the storage or handling of the samples (Oliveira et al., 2016). The second mass loss, occurred between 600 and $700{ }^{\circ} \mathrm{C}$, could be due to the decomposition of groups formed on carbon surface during activation process (carbonyl groups, ethers, structures of pyrone) and/or also by the decomposition of the carbon skeleton (Oliveira et al., 2016). The small loss of mass over a wide temperature range provides the desired stability to activated carbon.

\section{CONCLUSIONS}

Temperature and atmosphere of activation had significant effects on physico-chemical characteristics but did not present interaction between them. Samples presented a microporous profile for both atmospheres, indicating their high capacity to adsorb organic molecules of small dimensions. Pore distribution was not affected by activation atmosphere and the results for specific surface area confirmed the quality of woody Brazil nut seed capsule as precursor for activated carbon. Considering the results, activation by steam at $800{ }^{\circ} \mathrm{C}$ led an activated carbon with better quality.

\section{REFERENCES}

Ahmad AL, Loh MM, Aziz JA. Preparation and characterization of activated carbon from oil palm wood and its evaluation on Methylene blue adsorption. Dye Pigm. 2007;75(2):263-72. doi:10.1016/j.dyepig.2006.05.034.

Ahmedna M, Marshall WE, Rao RM. Surface properties of granular activated carbons from agricultural by-products and their effects on raw sugar decolorization. Bioresour Technol. 2000;71(2):103-12. doi.org/10.1016/S09608524(99)90069-X.

Alkhatib AJ, Zailaey KAl. Medical and environmental applications of activated charcoal : review article. Eur Sci J. 2015;11(3):50-6.

Anisuzzaman SM, Joseph CG, Daud WMABW, Krishnaiah D, Yee HS. Preparation and characterization of activated carbon from Typha orientalis leaves. Int J Ind Chem. 2015;6(1):9-21. doi:10.1007/s40090-014-0027-3.

ASTM D 1762-84. Standard test method for chemical analysis of wood charcoal. ASTM Int. 2007;84:1-2. doi: 10.1520/D1762-84R07.

ASTM D 2854-09. Standard test method for apparent density of activated carbon. ASTM Stand. 2009;96:1-3. doi: 10.1520/D2854-09.

ASTM D 3838-80. Standard test method for $\mathrm{pH}$ of activated carbon. ASTM Stand. 1999;15:1-3. doi: 10.1520/D3838-80R99.

Aznar JS. Characterization of activated carbon produced from coffee residues by chemical and physical activation. KTH Vetenskap och Konst. 2011. 65p.

\section{Revista Árvore 2019;43(2):e430206}

\section{sitf}


Bautista-Toledo I, Ferro-García MA, Rivera-Utrilla J, Moreno-Castilla C, Vegas Fernández FJ. Bisphenol a removal from water by activated carbon. Effects of carbon characteristics and solution chemistry. Environ Sci Technol. 2005;39(16):6246-50. doi:10.1021/es0481169.

Bhatnagar A, Sillanpää M. Utilization of agroindustrial and municipal waste materials as potential adsorbents for water treatment: a review. Chem Eng J. 2010;157(2-3):277-96. doi:10.1016/j. cej.2010.01.007.

Boas MAV, Carneiro ACO, Vital BR, Carvalho AMML, Martins MA. Efeito da temperatura de carbonização e dos resíduos de macaúba na produção de carvão vegetal. Sci For Sci. 2010;38(87):481-90.

Borges RM, Minillo A, Lemos EGM, Prado HFA, Tangerino EP. Use of granular activated carbon filters associated with microorganisms to remove pharmaceuticals in drinking water treatment. Eng Sanit e Ambient. 2016;21(4):709-20. doi:10.1590/ s1413-41522016118787.

Brito JO, Tomazello Filho M, Salgado ALB. Produção e caracterização do carvão vegetal de espécies e variedades de bambu. IPEF. 1987;36:13-7.

Brum SS, Bianchi ML, Silva VL, Gonçalves M, Guerreiro MC, Oliveira LCA. Preparação e caracterização de carvão ativado produzido a partir de resíduos do beneficiamento do café. Quím Nova. 2008;31(5):1048-52. doi:10.1590/S010040422008000500019 .

Collet F. Estudos comparativos, em escala de laboratório, de diversas madeiras utilizadas na fabricação de carvão vegetal. ABM. 1956;12(42):5-14.

Daud WMAW, Ali WSW, Sulaiman MZ. The effects of carbonization temperature on pore development in palm-shell-based activated carbon. Carbon. 2000;38(14):1925-32. doi:10.1016/S00086223(00)00028-2.

Djilani C, Zaghdoudi R, Djazi F, Bouchekima B, Lallam A, Magri P. Preparation and characterisation of activated carbon from animal bones and its application for removal of organic micropollutants from aqueous solution. Desalin Water Treat. 2016;57(52):25070-79. doi:10.1080/19443994.2016 .1151379 .
El-Sayed Y, Bandosz TJ. Adsorption of valeric acid from aqueous solution onto activated carbons: role of surface basic sites. J Colloid Interface Sci. 2004;273(1):64-72. doi:10.1016/j.jcis.2003.10.006.

ESTATCAMP. DIGUP. Action Stat Pro - 2017. Software de estatística.

Gomez-Serrano V, Pastor-Villegas J, Perez-Florindo A, Duran-Valle C, Valenzuela-Calahorro C. FTIR study of rockrose and of char and activated carbon. J Anal Appl Pyrolysis. 1996;36(1):71-80. doi:10.1016/0165-2370(95)00921-3.

Gottipati R, Adiraju B, Mishra S. Application of granular activated carbon developed from agricultural waste as a natural gas storage vehicle. IACSIT Int J Eng Technol. 2012;4(4):468-70. doi: 10.7763/IJET.2012.V4.412.

Herzog A, Reznik B, Chen T, Graule T, Vogt U. Structural changes in activated wood-based carbons: correlation between specific surface area and localization of molecular-sized pores. Holzforschung. 2006;60(1):85-92. doi:10.1515/HF.2006.015.

Jagtoyen M, Thwaites M, Stencel J, McEnaney B, Derbyshire F. Adsorbent carbon synthesis from coals by phosphoric acid activation. Carbon. 1992;30(7):1089-96. doi:10.1016/00086223(92)90140-R.

Jaguaribe EF, Medeiros LL, Barreto MCS, Araujo LP. The performance of activated carbons from sugarcane bagasse, babassu, and coconut shells in removing residual chlorine. Braz J Chem Eng. 2005;22(1):41-7. doi:10.1590/S010466322005000100005 .

Kawano T, Kubota M, Onyango MS, Watanabe F, Matsuda H. Preparation of activated carbon from petroleum coke by $\mathrm{KOH}$ chemical activation for adsorption heat pump. Appl Therm Eng. 2008;28(8-9):865-71. doi.org/10.1016/j. applthermaleng.2007.07.009.

Leon y Leon CA, Solar JM, Calemma V, Radovic LR. Evidence for the protonation of basal plane sites on carbon. Carbon. 1992;30(5):797-11. doi:10.1016/0008-6223(92)90164-R.

Lopes CW, Bertella F, Finger PH, Dallago RM, Pergher SBC, Penha FG. Synthesis and 
characterization of activated carbons derived from corn cob. Perspectiva. 2013;37(139):27-35.

Lua AC, Guo J. Preparation and characterization of activated carbons from oil-palm stones for gas-phase adsorption. Colloids Surfaces A Physicochem Eng Asp. 2001;179(2-3):151-62. doi:10.1016/S09277757(00)00651-8.

Maciá-Agulló JA, Moore BC, Cazorla-Amorós D, Linares-Solano A. Activation of coal tar pitch carbon fibres : Physical activation vs . chemical activation. Carbon. 2004;42(7):1367-70. doi:10.1016/j. carbon.2004.01.013.

Melo SS, Diniz JEM, Guimarães JH, Costa JS, Brasil DSB, Morais SSS, et al. Production and characterization of absorbent heat from the bark of residual Brazil nut bark (Bertholletia Excelsa 1.). Chem Cent J. 2015;9:36. doi:10.1186/s13065-0150114-3.

Mohan D, Pittman Jr. CU. Activated carbons and low cost adsorbents for remediation of triand hexavalent chromium from water. J Hazard Mater. 2006;137(2):762-11. doi:10.1016/j. jhazmat.2006.06.060.

Nobre JRC, Castro JP, Bianchi ML, Borges WMS, Trugilho PF, Moulin JC, et al. Characterization of activated carbon produced from sawdust massaranduba. Sci For Sci. 2015;43(107):693-02.

Nobre JRC, Castro JP, Motta JP, Bianchi ML, Trugilho PF, Borges WMS, et al. Activated carbon production of the wood residue of the Amazonian area. Sci For. 2015;43(108):895-06. doi:10.18671/ scifor.v43n108.14.

Oliveira GF, Andrade RC, Trindade MAG, Andrade HMC, Carvalho CT. Thermogravimetric and spectroscopic study (TG-DTA/FT-IR) of activated carbon from the renewable biomass source Babassu. Quím Nova. 2017;40(3):284-92. doi:10.21577/01004042.20160191

Pastor-Villegas J, Gómez-Serrano V, Durán-Valle CJ., Higes-Rolando FJ. Chemical study of extracted rockrose and of chars and activated carbons prepared at different temperatures. J Anal Appl Pyrolysis. 1999;50(1):1-16. doi:10.1016/S01652370(99)00022-4.
Pereira MFR, Soares SF, Órfão JJM, Figueiredo JL. Adsorption of dyes on activated carbons: influence of surface chemical groups. Carbon. 2003;41(4):81121. doi:10.1016/S0008-6223(02)00406-2.

Pinheiro PCC, Figueiredo FJ, Séye O. Influence of temperature and carbonization heating rate on the properties of Eucalyptus charcoal. Biomassa Energ. 2005;2(2):159-68.

Prauchner MJ, Rodríguez-Reinoso F. Chemical versus physical activation of coconut shell: a comparative study. Microporous Mesoporous Mater. 2012;152(1):163-71. doi:10.1016/j. micromeso.2011.11.040

Rambo MKD, Alexandre GP, Rambo MCD, Alves AR, Garcia WT, Baruque E. Characterization of biomasses from the north and northeast regions of Brazil for processes in biorefineries. Food Sci Technol. 2015;35(4):605-11. doi:10.1590/1678457X.6704.

Ramos PH, Guerreiro MC, Resende EC, Gonçalves M. Produção e caracterização de carvão ativado produzido a partir do defeito preto, verde, ardido (PVA) do café. Quím Nova. 2009;32(5):1139-43. doi.org/10.1590/S0100-40422009000500011.

Rodríguez-Reinoso F, Molina-Sabio M, González MT. The use of steam and $\mathrm{CO} 2$ as activating agents in the preparation of activated carbons. Carbon. 1995;33(1):15-23. doi:10.1016/00086223(94)00100-E.

Rodriguez-Reinoso F, Silvestre-Albero J. Activated Carbon and Adsorption. Ref Modul Mater Sci Mater Eng. 2016:1-14. doi:10.1016/B978-0-12-8035818.02289-X.

Róz AL, Ricardo JFC, Nakashima GT, Santos LRO, Yamaji FM. Maximização do teor de carbono fixo em biocarvão aplicado ao sequestro de carbono. Rev Bras Eng Agrícola e Ambient. 2015;19(8):810-14. doi:10.1590/1807-1929/agriambi.v19n8p810-814.

Salame II, Bandosz TJ. Surface chemistry of activated carbons: combining the results of temperature-programmed desorption, Boehm, and potentiometric titrations. J Colloid Interface Sci. 2001;240(1):252-58. doi:10.1006/jcis.2001.7596.

Scussel VM, Manfio D, Savi GD, Moecke EHS. 
Stereoscopy and Scanning Electron Microscopy of Brazil Nut (Bertholletia excelsa H.B.K.) Shell, Brown Skin, and Edible Part: Part OneHealthy Nut. J Food Sci. 2014;79(7):1443-53. doi:10.1111/1750-3841.12502.

Shaji A, Zachariah AK. Surface Area Analysis of Nanomaterials. Therm. Rheol. Meas. Tech. Nanomater. Charact. Elsevier. 2017:197-231. doi:10.1016/B978-0-323-46139-9.00009-8.

Silva DA, Brito JO. Pirólise de turfa e análise do seu carvão. Acta Amaz. 1990;20:283-05. doi. org/10.1590/1809-43921990201300.

Sing KSW, Everett DH, Haul RAW, Moscou L, Pierotti RA, Rouquérol J, et al. Reporting physisorption data for gas/solid systems with special reference to the determination of surface area and porosity. Pure Appl Chem. 1985;57(4):603-19. doi:10.1351/ pac198557040603.

Strelko Jr V, Malik DJ. Characterization and metal sorptive properties of oxidized active carbon. J Colloid Interface Sci. 2002;250(1):213-20. doi:10.1006/jcis.2002.8313.

Sun Y, Webley PA. Preparation of activated carbons from corncob with large specific surface area by a variety of chemical activators and their application in gas storage. Chem Eng J.
2010;162(3):883-92. doi:10.1016/j.cej.2010.06.031.

Tsai WT, Chang CY, Wang SY, Chang CF, Chien SF, Sun HF. Preparation of activated carbons from corn cob catalyzed by potassium salts and subsequent gasification with $\mathrm{CO} 2$. Bioresour Technol. 2001;78(2):203-8. doi:10.1016/S09608524(00)00111-5.

Wibowo N, Setyadhi L, Wibowo D, Setiawan J, Ismadji S. Adsorption of benzene and toluene from aqueous solutions onto activated carbon and its acid and heat treated forms: Influence of surface chemistry on adsorption. J Hazard Mater. 2007;146(1-2):237-42. doi:10.1016/j. jhazmat.2006.12.011.

Yang H, Yan R, Chen H, Lee DH, Zheng C. Characteristics of hemicellulose, cellulose and lignin pyrolysis. Fuel. 2007;86(12-13):1781-88. doi:10.1016/j.fuel.2006.12.013.

Yang T, Lua AC. Characteristics of activated carbons prepared from pistachio-nut shells by physical activation. J Colloid Interface Sci. 2003;267(2):40817. doi:10.1016/S0021-9797(03)00689-1.

Zhang T, Walawender WP, Fan LT, Fan M, Daugaard D, Brown RC. Preparation of activated carbon from forest and agricultural residues through $\mathrm{CO} 2$ activation. Chem Eng J. 2004;105(1-2):53-9. doi:10.1016/j.cej.2004.06.011. 